\title{
IMMUNOBLOT PROFILES OF SERA FROM LABORATORY RATS NATURALLY INFECTED WITH MYCOPLASMA PULMONIS AND TECHNICIANS EXPOSED TO INFECTED ANIMAL FACILITIES
}

\author{
Márcio Oliveira Delgado ${ }^{1}$; Jorge Timenetsky ${ }^{2 *}$ \\ Departamento de Microbiologia, Instituto de Ciências Biomédicas, Universidade de São Paulo, São Paulo, SP, Brasil
}

Submitted: June 16, 2001; Approved: November 21, 2001

\begin{abstract}
Mycoplasma pulmonis have been isolated in about $10^{5} \mathrm{CFU} / \mathrm{mL}$ from tracheal aspirates of rats from conventional animal facilities in São Paulo. The mycoplasma transmission by aerosol may happen from an infected rat to a healthy one at distances up to $120 \mathrm{~cm}$. This condition also favors the technicians contamination. As this infection is unknown in humans, in this study the immunoblot profiles to M. pulmonis of sera from rats were compared to those presented by animal facility technicians. About 32 proteins from 11 to $230 \mathrm{kDa}$ (kilodaltons) were recognized by the sera from rats naturally infected with $M$. pulmonis. Sera from technicians responsible for the cleaning and sanitation of cages of infected animals for more than seven years recognized about 10 proteins of this bacteria. Sera from individuals with shorter working time or that had never been exposed to such environment recognized few proteins. Proteins about 117 and $95 \mathrm{kDa}$ were recognized by human and rat sera and by the negative controls. Although a positive human serum against M. pulmonis is unknown, this study established a temporary profile of protein recognition of human serum against such mycoplasma.
\end{abstract}

Key words: Mycoplasma pulmonis, human sera, animal facilities.

\section{INTRODUCTION}

Mycoplasma pulmonis is the most frequent mycoplasma isolated from rats and causes the Murine Respiratory Mycoplasmosis (MRM) that can be chronic or asymptomatic (8). In a previous study, about $10^{5} \mathrm{CFU} / \mathrm{ml}$ of $M$. pulmonis were detected in tracheal aspirates of rats (18). MRM has been recognized as a major disease in laboratory rats and mice. Mycoplasma infection in laboratory animals interferes on the results of biomedical research $(8,11)$. This issue has been documented in many aspects, but there is little information about immunoblot profiles of sera from rats naturally infected by $M$. pulmonis. The citations are related with immunoenzimatic tests of animal colony screenings (12).

The transmission of $M$. pulmonis by aerosols from an infected to a healthy rat by sneezing in a distance of about 120 $\mathrm{cm}$ (16) strongly suggests that such condition may happen between rats and humans (22). The technicians attending the cleaning of cages of facilities with rats infected with M pulmonis are the candidates to be infected with these bacteria. Exposure of humans to $M$. pulmonis was not considered yet because rodents are the natural hosts. Although mycoplasmas show specificity to their hosts, isolation of some mycoplasmas from unusual hosts was already reported $(1,2,4,14,21,24)$. In order to verify possible transmission of $M$. pulmonis to humans from rats, the present study has the goal to compare the immunoblot profiles of sera from technicians working at laboratory animal facilities and sera from rats naturally infected with M. pulmonis.

\section{MATERIALS AND METHODS}

\section{Mycoplasma antigen}

Two antigens were tested: the total lysate of $M$. pulmonis NCTC 10139 and the total lysate from the isolate Q10, obtained

\footnotetext{
* Corresponding Author. Mailing address: Departamento de Microbiologia, ICB II, USP. Av. Prof. Lineu Prestes, 1374, Cidade Universitária. 05508900, São Paulo, SP, Brasil. Fax: (+5511) 3091-7354. E-mail: jtimenet@icb.usp.br
} 
from a tracheal aspirate of naturally infected rat. Briefly, after growing in $1000 \mathrm{ml}$ of SP4 medium(20), mycoplasma cells were concentrated by centrifugation at 20,449 $\mathrm{g}$ for 50 minutes, at $4^{\circ} \mathrm{C}$, washed three times by successive centrifugations (28,663 $g, 30$ minutes, $4^{\circ} \mathrm{C}$ ) and homogenized with PBS (15).

\section{Sera}

Forty sera from Wistar rats (Rattus norvegicus - 50\% female and $50 \%$ male - 45 to 60 days old) of six different facilities were used. Nonclimate-controlled facilities in our region are defined as follows: light cycle of $12 \mathrm{hs}$, without air-conditioning but ventilated; temperature about 24 to $28^{\circ} \mathrm{C}$ and humidity from 40 to $80 \%$. After euthanasia with an intraperitoneal overdose of pentobarbital, a sample of tracheal aspirate was obtained for mycoplasma isolation (18). Then, about $3 \mathrm{ml}$ of blood was punctured from the heart and the serum was separated. Twentyeight human (volunteers) sera were obtained from $10 \mathrm{~mL}$ of blood venipunctured from technicians working up to 15 years in different facilities with infected animals on the cleaning of rats cages. Twelve sera samples were from individuals that had never been in animal facilities. The human care and the use of animals were previously attested by the supervisors of each animal facility. The purpose of the study was previously explained to the supervisors and volunteers.

\section{Electrophoresis and immunoblots}

About $300 \mu \mathrm{g}$ of antigen were electrophoresed on $12 \%$ SDSPAGE and electrotransferred to nitrocellulose membranes. The membranes were blocked with TBS (20mMTris; $500 \mathrm{mM} \mathrm{NaCl}$, $\mathrm{pH} 7.5$ ) with 5\% nonfat milk and cut into $4 \mathrm{~mm}$ width strips. Sera from rats, technicians and individuals who have never had contact with rats in animal houses were diluted 1:100 in TBS with $5 \%$ of nonfat milk and incubated for 2 hours with the strips. Hyperimmune horse serum to M. pulmonis was included as positive control. After washings, alkaline phosphatase-anti IgG conjugates against each specific serum were added and incubated for 2 hours. The recognized proteins on the membranes were detected by NBT/BCIP (Nitro-blue tetrazolium/ 5-bhromide 4-chloride 3-indolil phosphate) substrates and the reaction was interrupted with distilled water (3).

\section{RESULTS}

The most representative profiles obtained immunobloting human and rat sera to M. pulmonis NCTC 10139 are presented in Fig. 1. Results for the indigenous strain Q 10 were very similar and are not shown. All sera recognized bands about 117 and 95 $\mathrm{kDa}$. Sera from infected rats recognized not identically about 33 proteins, ranging approximately from 11 to $230 \mathrm{kDa}$ (lanes 3 to 16). Most of the recognized bands were from 36 to $230 \mathrm{kDa}$. Serum from a non-infected rat (lane 1) recognized bands about

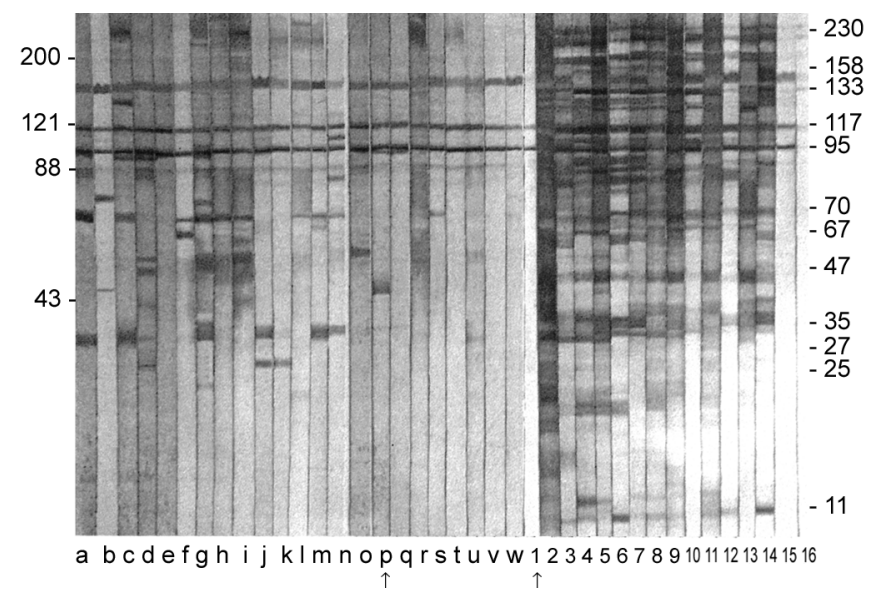

Figure 1: Immunoblot profiles of human and rat sera against $M$. pulmonis NCTC 10139. Sera on lanes $\boldsymbol{a}$ to $\boldsymbol{p}$ : are from technicians with 7 to 15 years in contact with rats in animal facilities. Sera on lanes $\boldsymbol{q}$ to $\boldsymbol{u}$ : are from individuals with less than 7 years of exposure. Lane $\boldsymbol{w}$ represent a serum from an individual without exposure to rats. Serum on lane $\boldsymbol{1}$ is from a non infected rat. On lane 2 is a horse hyperimmune serum to M. pulmonis. Sera on lanes $\mathbf{3}$ to $\mathbf{1 6}$ are from rats naturally infected with $M$. pulmonis. Numbers: molecular weight in $\mathrm{kDa}$.

117 and $95 \mathrm{kDa}$ and the hyperimmune horse serum (lane 2) recognized the higher number of bands. Although sera on lanes $\mathbf{1 5}$ and $\mathbf{1 6}$ are from infected rats they recognized weakly a few bands.

Sera from technicians are on lanes a to $\mathbf{w}$. Sera on lanes a to $\mathbf{p}$ are from individuals that have had contact with infected animals from 7 to 15 years, and recognized much less bands than rats. Most of the recognized bands by human sera ranged approximately from 25 to $200 \mathrm{kDa}$ and sera from rats recognized bands with the same Molecular Weight. All human sera recognized a band of about $156 \mathrm{kDa}$. However this protein was not recognized by a noninfected rat as did some sera from infected rats (lanes 1, 4, 8,13 and 16). The band about $70 \mathrm{kDa}$ was the protein most frequently recognized by sera from technicians with more time of exposure to infected facilities. The band just below $95 \mathrm{kDa}$ was recognized by four sera shown on lanes $\mathbf{c}, \mathbf{d}, \mathbf{g}$ and $\mathbf{p}$. A band between 117 and $95 \mathrm{kDa}$ was recognized on lane $\mathbf{n}$ as did some sera from infected rats. Bands about 25 to $35 \mathrm{kDa}$ and bands just above $47 \mathrm{kDa}$ were recognized by sera from individuals with more time of exposure to infected facilities. This also happens not regularly with other MW proteins on $\mathbf{b}, \mathbf{c}, \mathbf{d}, \mathbf{f}, \mathbf{g}, \mathbf{j}$ and $\mathbf{l}$. Sera from individuals that had never been in animal facilities presented an identical profile as shown on lane $\mathbf{w}$. The profile of this lane was obtained from an individual after one year of working in such environment. 


\section{DISCUSSION}

M. pulmonis infects laboratory animals worldwide. Most of the animal facilities in Brazil do not control mycoplasmas by culture or serology (19). The recovery of M. pulmonis in about $10^{5} \mathrm{CFU} / \mathrm{mL}$ from tracheal aspirates of rats and the aerosol generated by infected rats in animal facilities favor the transmission of this bacterium to humans. The culture of this specie from a colonized human mouth is very difficult because there are other mycoplasma species as normal flora.

The present study shows that sera from naturally infected rats by mycoplasma of six animal facilities recognized many proteins from the total lysate of M. pulmonis cells. Immunoblot profile differences can be justified by the variation on immune response of each rat, antigenic variation and different stages of the natural infection (6). A pattern of recognized bands of about ten or more proteins indicates that the animal could be infected by $M$. pulmonis. This is supported by the fact that the serum from an infected animal recognizes better and more proteins from the infected microorganism than from any other (12). Most of the immunoblot profiles obtained from sera of rats are coincident with the M. pulmonis isolations and at least 10 bands were recognized. The hyperimmune serum has a recognition profile similar to most naturally infected animals.

Sera from humans recognized less proteins to M. pulmonis than sera from rats, but human sera recognized some proteins with similar Molecular Weight that sera from infected rats. Sera from technicians with more than seven years of exposure to animal facilities recognized more and better $M$. pulmonis proteins than sera from individuals with shorter exposure time to infected rats or those that have never had contact with rodents. This indicates that the time of exposure of technicians to infected rats is related to the differences immunoblot profiles.

Differences on protein recognition profiles between humans and rats can be explained by the fact that the exposure to such agent by different hosts is not identical (7). Microbial infections on different anatomical sites may also result in different immune response to the same microorganism. Different hosts may recognize different epitopes of the same antigen, resulting on distinct recognition patterns (10). Adaptation to the host is another feature for antigenic variation in mycoplasmas and could mimicry the immune response. $(5,23)$. Mycoplasmas also possess modulins that should be also considered in human exposure to these bacteria from other hosts.

Negative serum from a non infected rat and sera from all tested individuals recognized proteins of about 117 and $95 \mathrm{kDa}$. This indicates that these proteins are cross-reactive and should not be considered as a reference profile for rats and humans. However the sera from infected rats recognized these proteins more intensively.

Cross reactions among mycoplasmas and others microorganisms have already been described $(9,13)$. M. pulmonis cross react with $M$. arthritidis, a specie less frequently isolated from murines (15). In this study, it was also observed that sera from rats and humans did not recognize proteins of total lysate of a reference strain of M. arthritidis-PG6 and this specie was not isolated from rats in this study.

Although humans have a mycoplasma flora on mucosal surfaces of oropharynx and genital tract, the cross reactions are described between M. pneumoniae and M. genitalium (17). In addition rat sera did not recognize proteins of total lysates of reference strains of $M$. pneumoniae- $\mathrm{FH}, M$. hominis-PG21, $M$. orale-CH19299, M. buccale-CH20247 and M. salivarium PG20. Cross reactions in some animal origin mycoplasmas were reported but they are unknown to humans and vice-versa.

Cross reactions between human and murine mycoplasmas are also unknown but in the present study the proteins of about 117 and $95 \mathrm{kDa}$ were shown to be cross reactive between rats and humans. The protein of about $156 \mathrm{kDa}$ may also be considered a cross-reactive protein in human sera but not in all sera from rats.

Although a human serum positive to $M$. pulmonis is unknown and so are studies on this topic, the present results indicate that this mycoplasma promotes distinct immunoblot profile of sera from technicians exposed for more than seven years to this mycoplasma. For a better comprehension of this issue, studies with larger numbers of samples of sera from technicians exposed to infected animal facilities must be performed.

\section{ACKNOWLEDGEMENTS}

This work was supported by a Scholarship to M.O.D. and funds from FAPESP.

\section{RESUMO}

\section{Imunoeletroforese do soro de ratos naturalmente infectados com Mycoplasma pulmonis e bioteristas expostos a biotérios infectados}

Mycoplasma pulmonis foi isolado em aproximadamente $10^{5} \mathrm{UFC} / \mathrm{mL}$ do lavado traqueal de ratos mantidos em biotérios convencionais da cidade de São Paulo. A transmissão do micoplasma por aerossol pode ocorrer entre os animais em até $120 \mathrm{~cm}$. Esta condição favorece a sua transmissão para os bioteristas que também são expostos a este microrganismo. Como esta colonização é desconhecida em humanos, as imunoeletroforeses dos soros destes indivíduos foram comparados à com os dos ratos. Aproximadamente 32 proteínas de 11 a $230 \mathrm{kDa}$ foram reconhecidas pelo soros dos ratos naturalmente infectados com M. pulmonis. Os soros dos bioteristas que estão envolvidos por mais de 7 anos na higenização das caixas com animais infectados reconheceram 
cerca de 10 proteínas deste microrganismo. O soro de indivíduos com menos tempo de serviço neste ambiente ou aqueles que nunca estiveram em biotérios reconhecerem poucas proteínas. As proteínas de aproxi-madamente 117 and $95 \mathrm{kDa}$ foram reconhecidas pelo soro de ratos, humanos e soros controle negativos. Embora desconhece-se um soro humano positivo contra $M$. pulmonis, este estudo apresenta o perfil imunoeletroforético dos indivíduos expostos a este microrganismo.

Palavras-chave: Mycoplasma pulmonis, soro humano, biotérios.

\section{REFERENCES}

1 - Armstrong, C.H.; Yu, B.H.; Yagoda, A. Kagnoff, M.F. 1971. Colonization of human by Mycoplasma canis. J. Infect. Dis., 124: 607-09.

2- Baker, A.S.; Ruoff, K.L.; Madoff, S. 1998. Isolation of Mycoplasma species from a patient with seal finger. Clin. Infect. Dis., 27: 1168-70.

3 - Bollag, D.M., Rozycki, M.D., Edelstein, S.J. 1996. Protein methods. 2.ed. Wiley-Liss, New York.

4- Bonilla, H.F.; Chenoweth, C.E.; Tully, J.G.; Blythe, L.K.; Robertson, J.A.; Ognenovski, V.M.; Kauffman, C.A. 1997. Mycoplasma felis septic arthritis in a patient with hipogammaglobulinemia. Clin. Infect. Dis., 24: 222- 25.

5- Chambaud, I.; Wróblewski, H.A.; Blanchard. 1999. Interactions between mycoplasma lipoproteins and host immune system. Trends in Microbiology, 7: 2. 493-499.

6- Chang, J.; Pick, J.R. 1986. Immunoreactive protein antigens of Mycoplasma pulmonis in experimentally infected rats. Am. J. Vet. Res., 47: 1901-04.

7- Cole, B.C. 1996. Mycoplasma interactions with the immune system: implications for disease pathology. ASM News, 62: 471-75.

8- Davidson, M.K.; Davis, J.K.; Gambill, G.P.; Cassell, G.H.; Lindsey, J.R. 1994. Mycoplasmas of laboratory rodents. p.97-133. In: Whitford, H.W.; Rosenbusch, R.F.; Lauerman, L.H. (eds.), Mycoplasmosis in animals: laboratory diagnosis. Iowa State Univ. Press, Iowa.

9- Elgert, K.D. Immunology: understanding the immune system. WileyLiss, Inc., N. York, 1996.
10- Jacobs, E. 1991. Mycoplasma pneumoniae virulence factors and the immune response. Rev. Med. Microbiol., 2: 83-90.

11 - Kohn, D.F.; Barthold, S.W. 1984. Biology and diseases of rats. In: Laboratory animal medicine. Academic press, New York.

12- Simecka, J.W.; Davis, J.K.; Davidson, M.K.; Ross, S.E.; Stadtlander, C.T.K.; Cassel, G.H. 1992. p.3991-415. Mycoplasma disease of animals. In: Maniloff, J.; McElhaney, R.N.; Finch, L.R.; Baseman, J.B. (eds), Mycoplasmas: molecular biology and pathogenesis. ASM Press, Washington, DC.

13- Sondergard-Andersen, M.A.; Jensen, J.S.; Uldum, S.A.; Lind, K. 1990. Heat shock protein in Mycoplasma pneumoniae show by immunoblotting to be related to the bacterial common antigen. $J$. Infect. Dis., 161: 1039-40.

14- McCabe, S.J.; Murray, J.T.; Ruhnke, H.L.; Rachilis, A. 1987. Mycoplasma infection of the hand acquired from a cat. J. Hand. Surg., 12: 1085-99.

15- Minion, F.C.; Brown, M.B.; Cassell, G.H. 1984. Identification of cross reactive antigens between Mycoplasma pulmonis e $M$. arthritidis. Infect. Immun., 43: 115-21.

16- Mistscherlich, E.; Marth, E.H. 1984. Microbial survival in the environment, bacteria and ricketsiae. Springer-Verlag. New York.

17- Taylor-Robinson D.; Furr, P.M.; Tully, J.G. Serological cross reactions between Mycoplasma genitalium and M. pneumoniae [letter]. Lancet, 1983; 1: 527.

18- Timenetsky, J.; De Lucca, R.R. 1998. Detection of M. pulmonis from rats and mice, São Paulo/SP, Brazil. Lab. Anim. Sci., 48(2): 210-213.

19- Timenetsky, J. Micoplasmas e a pesquisa biomédica. 2000. Laes \& Haes, Brazil. 122: 92-102.

20- Tully, J.G. 1996. Culture medium formulation for primary isolation and maintenance of mollicutes. p.33-40. In: Tully, J.G.; Razin, S.(eds.), Molecular and diagnostic procedures in mycoplasmology, v.1. Academic press, San Diego, CA.

21 - Waits, K.B.; Tully, J.G.; Rose, D.L.; Marriott, P.A.; Davis, R.O.; Cassell, G.H. 1987. Isolation of Acholeplasma oculi from human amniotic fluid in early pregnancy .Curr. Microbiol., 15: 325- 27.

22- Wathes, C.M. Bioaerosols in animal houses. 1995. p.547-78. In: Cox, C.S.; Wathes, C.M. (eds.), Bioaerosols handbook. CRC press, New York.

23 - Watson, H.L.; Dybvig, K.; Blalock, D.K.; Cassell, G.H. 1989. Subunit structure of the variable v- 1 antigen of Mycoplasma pulmonis. Infect. Immun., 57: 1684-90.

24- Yechouron, A.; Lefebvre, J.; Robson, H.G.; Rose, D.L.; Tully, J.G. 1992. Fatal septicemia with Mycoplasma arginini: a new human zoonosis. Clin.Infect.Dis., 15: 434- 38. 